\title{
点群データ分類と自動位置合わせの高速化
}

\section{Classification of Cloud Points and High-Speed Automatic Registration}

\author{
趙希禄・埼玉工業大学
}

Xilu ZHAO, Saitama Institute of Technology

徐放・住友重機械工業

Fang XU, Sumitomo Heavy Industries, Ltd
萩原一郎・明治大学

Ichiro HAGIWARA, Meiji University

Key Words: Reverse engineering, Automatic registration, Shape measurement, Computer aided design, Image Processing

1. はじめに

リバースエンジニアリングにおいて，異なる視点で測定し た距離画像の自動位置合わせ問題は非常に重要な研究課題 になっている(1). 位置合わせの目的は異なる視点から計測し た距離画像をべースにして, 重ねた部分の正しい相対位置関 係を表せるデータ変換関倸を求めることである(2)-(3).

本文では, 各点の近傍点の共分散行列の固有值分析を行い, 得られた固有ベクトルをべースにし，点群を平滑点，折目点、 角点と境界点に分類して, 更に, 同種類の点に対して全体的 な位置パラメータを計算し，高速かつ正確な自動位置合わせ 方法を検討する。

\section{2. 点の分類}

まず，任意の注目点 $p_{i}$ とその近傍点 $q_{j}\left(j=1,2, \ldots . . ., N_{i}\right)$ を考える. その近傍点の中心 $c_{i}$ を次式のように表される.

$$
c_{i}=\frac{1}{N_{i}} \sum_{j=1}^{N_{i}} q_{j}
$$

そして, 近傍点の共分散行列が次式のように定義できる.

$$
C_{i}=\sum_{i=1}^{N_{1}}\left(q_{j}-c_{i}\right)\left(q_{j}-c_{i}\right)^{T}
$$

式中では, $q_{j}-c_{i}$ は $3 \times 1$ の列ベクトル, $C_{i}$ は $3 \times 3$ の共分 散行列である. $C_{i}$ に対して固有値解析を行い, 得られた固 有べクトル $e_{0}, e_{1}, e_{2}$ とそれに対応する固有值 $\lambda_{0}, \lambda_{1}, \lambda_{2}\left(\lambda_{0} \leq \lambda_{1} \leq \lambda_{2}\right)$ を利用して，点 $p_{i}$ を図 1 のように 4 種類に分類することができる.

(1) 平滑点 $p_{\text {suf }}$ 注目点 $p_{i}$ は滑らかな曲面にある場合, 固有值が $\lambda_{1} \approx \lambda_{2}$ そして $\lambda_{0} \approx 0$ となり, 図 1(a)に示すように, 平滑点の最小固有值に対応する固有ベクトル $e_{0}$ の方向は, $p_{i}$ の位置する曲面の法線べクトルとほぼ一致する. $e_{1}$ と $e_{2}$ はそれぞれ $e_{0}$ と直交しており，方向は決められない.

(2) 折目点 $p_{c r e}$ 図 1(b)に示すように注目点 $p_{i}$ が曲面と 曲面の交差する交線上にある場合, 固有值が $\lambda_{0} \approx \lambda_{1}$ そして $\lambda_{0}+\lambda_{1} \approx \lambda_{2}$ となり, $e_{2}$ が注目点 $p_{i}$ にある曲面と曲面の交線 の接線方向と一致する. $e_{0}$ が両曲面と同じ角度を持つ平面に あり，各方向が確定できる.

（3）境界点 $p_{b o r}$ 境界にある点を境界点 $p_{b o r}$ と定義する. 境界点の場合, $\lambda_{0} \approx 0$ そして $2 \lambda_{1} \approx \lambda_{2}$ になる. 対応する固有
ベクトルの関係は図 1(c)に示しており， $e_{0}$ は曲面の法線方向， $e_{2}$ は境界線の接線方向と一致する.

（4）角点 $p_{c o r}$ 角にある点を角点 $p_{c o r}$ とする. 固有べク トルの関係は複雑になって不確定になる. 図1(d)に示すよう に, 角の部分が複数の曲面の交線の交点と見なし, 各曲面の 挟む角度が異なり， $e_{0}$ だけの方向が決められる。

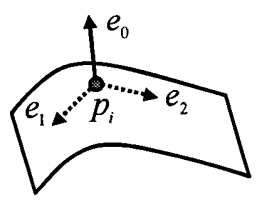

(a)Surface Point

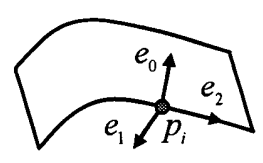

(c)Border Point

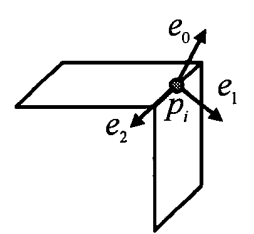

(b)Crease Point

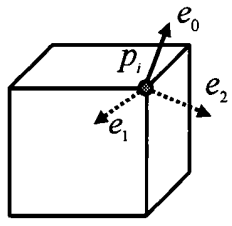

(d)Corner Point
Fig.1 Points Classification

\section{3. 自動位置合わせ}

図 2 に示す点群 $P$ を点群 $Q$ に変換する例を考える. 図中 では, 点 $p_{1}$ と $p_{2}$ は点群 $P$ の上にある対応点, 点 $q_{1}$ と $q_{2}$ は 点群 $Q$ の上にある対応点, $p_{c}$ は点群 $P$ の中心, 矢印は各点 の固有ベクトルである.

ここで，点の位置および固有べクトルを揃えるように，点 群 $P$ の対応点を点群 $Q$ の対応点に変換した結果を図 3 に示 す. 図 3 により，図 3(a)と(d)に示す $p_{1}$ と $q_{1}, p_{2}$ と $q_{2}$ によ る変換は正しく, 図 3(b)と(c)に示す $p_{1}$ と $q_{2}, p_{2}$ と $q_{1}$ によ る変換は間違ったことが判る.この結果を利用すれば自動位 置合わせを実現することができる．

まず，次式で点群 $P$ の中心 $p_{c}$ を計算する.

$$
p_{c}=\frac{1}{N} \sum_{i=1}^{N} p_{i}
$$

式中では, $N$ は点群 $P$ の点の総数である. 次式の共分散 行列の固有べクトル $e_{c 0}, e_{c 1}, e_{c 2}$ を求める. 


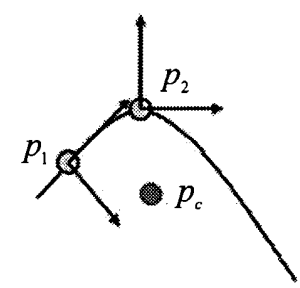

(a) Data $P$

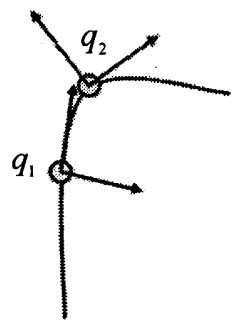

(b) Data $Q$
Fig. 2 Cloud Data and Corresponding Points

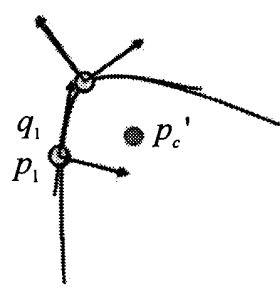

(a) Point $p_{1}$ and $q_{1}$

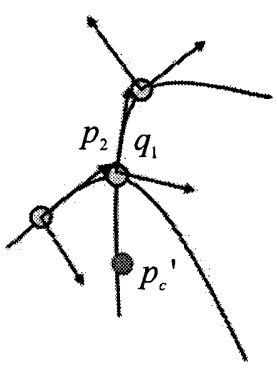

(c) point $p_{2}$ and $q_{1}$

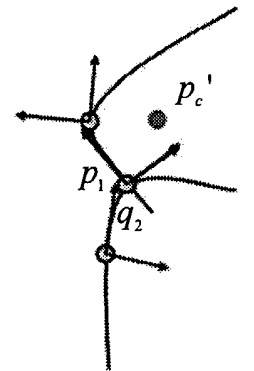

(b) Point $p_{1}$ and $q_{2}$

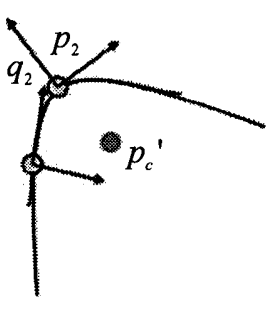

(d) Point $p_{2}$ and $q_{2}$
Fig.3 Transformation Using Different points

$$
C=\sum_{i=1}^{N}\left(p_{i}-p_{c}\right)\left(p_{i}-p_{c}\right)^{T}
$$

次に, 同じ種類の点 $p_{i} \in P$ と $q_{j} \in Q$ を選択して, 点 $p_{i}$ と 点 $q_{j}$ の固有ベクトルから構成する $3 \times 3$ の行列の間に次の関 係が存在する.

$$
D_{j}=T_{j i} D_{i}
$$

式(5)を整理して, 点 $p_{i}$ から点 $q_{j}$ への回転変換行列 $T_{j i}$ が 次式のように求められる。

$$
T_{j i}=D_{j} D_{i}^{-1}
$$

一方，点 $p_{i}$ から点 $q_{j}$ への並進変換ベクトルが次式のよう に求められる.

$$
d_{j i}=q_{j}-p_{i}
$$

ここで, 点群 $P$ を剛体として考え, 式(6)と(7)に示す回転 変換行列と並進変換行列を使い, 点群 $P$ の中心 $p_{c}$ を次式で 点群 $Q$ に変換する.

$$
p_{c}^{\prime}=T_{j i}\left(p_{c}-p_{i}\right)+d_{j i}
$$

式中では， $p_{c}^{\prime}$ は点群 $P$ の中心 $p_{c}$ を変換した点である. 点群 $P$ の中心 $p_{c}$ の固有べクトル $e_{c 0}, e_{c 1}, e_{c 2}$ を点群 $Q$ に変換 した後のベクトル $e_{c 0}^{\prime}, e_{c 1}^{\prime}, e_{c 2}^{\prime}$ が次式で求められる.

$$
e_{c k}^{\prime}=T_{j i} e_{c k} \quad(k=0,1,2)
$$

最後に, 点群 $P$ の全ての点について, 式(6)〜 (9)を使い, 回転変換行列と並進変換行列を求め, 点群 $P$ の中心を点群 $Q$ に変換して, 得られた沢山の中心点の中で, 正しく変換さ

れたのはある点に集中しており，この時の位置パラメータを 利用して, 点群 $P$ の全ての点を点群 $Q$ に変換すれば，位置 合わせを実現することができる．

図 4 に示すのは，モウスの位置合わせの例である．両方の 重ねた部分が少なく，そして重ねた部分には平滑点が多く， 全体的に特徵点が少ないモウスの点群データに対して自動 位置合わせを行った結果, 重ねた部分が非常に滑らかな曲面 となり，品質の良い位置合わせ結果が得られた。

図 5 に示すのは，オイルパンの位置合わせの結果である. 全体的に似ている特徵点が多く, 重ねた部分が比較的少ない オイルパンの点群データに対して自動位置合わせを行った 結果，点分類を行い，同じ種類の点同士だけをマッチングし ているため，正確な位置合わせ結果が得られた。

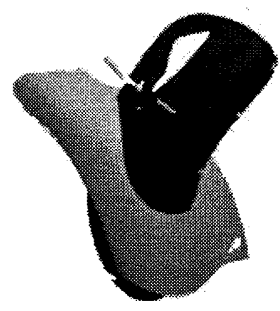

(a) Initial Position

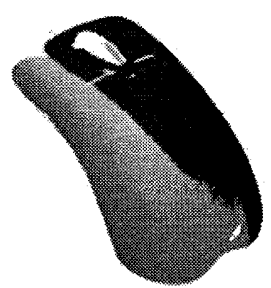

(b) After Registration Fig.4 Validation Result of Mouse

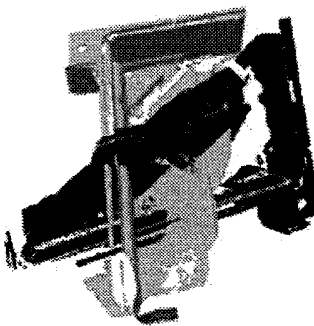

(a) Initial Position

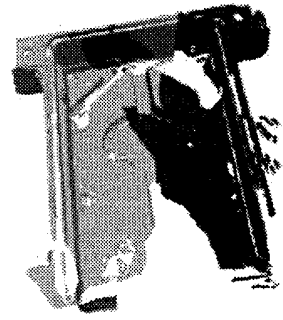

(b) After Registration Fig.5 Validation Result of Oil pan

\section{4. 結論}

（1）点群データの近傍点群を用いて生成した共分散行列に 対して固有值解析を行い，新しい点分類方法を提案した.

(2)点群データを平滑点、折目点、境界点と角点に明確に分 類することが実現できた.

（3）本法を用いて，従来の位置合わせ方法で処理できない 問題に対しても非常に有効であることを示している.

\section{謝 辞}

本研究は平成 24 年度科学研究費補助金 (基盤研究 $\mathrm{C}$, No.24560271）の援助を受けてなされた.ここに深甚なる感 謝の意を示す.

\section{参考文献}

[1] P. J. Besl and N.D. McKay, A Method for Registration of 3-D Shapes. IEEE Transactions on Pattern Analysis and Machine Intelligence, No.14 -2, (1992), pp. 239-256.

[2]徐放，趙希禄，萩原一郎，リバースエンジニアリングにお ける自動位置合わせに関する検討, 日本機械学会論文集 C 編, Vol.76, No.771，（2010 年），pp.2861-2869.

[3]徐放, 趙希禄, 萩原一郎, 多記述子点群モデルによる高速 自動位置合わせに関する研究, 日本機械学会論文集 C 編, Vol.78, No.787,（2012 年), pp.783-798. 